\title{
The Gender Education and the Necessity of Improving the Curricula in the Elementary Education - the Analysis of the Scholar Texts
}

\author{
Dr. Monika Hodaj \\ PhD in Psychology-Pedagogy at the faculty of the Social Sciences, Tirana, \\ The Speciality: Methodology and Teaching \\ mona_hodaj@yahoo.com
}

Doi:10.5901/ajis.2015.v4n1s1p129

Abstract

This study describes the gender steryotypes, portreid in figures and in sentenced like masculine and feminine in the texts of the primary cicle. The aim of this study is to explore the steryotypes connected with the gender roles, in the teaching text of the primary cicle in Albania. More specifically this study aims to identify the: 1.The frequency of the showing (presentation) of the characters feminines and masculines, the primary teaching text; 2. The way of the portraying the masculines and feminines connected to the family roles (house keeping in a family level); 3. The way of portraying the masculines and feminines connected to the professional roles and the activities away from home (economic and employment activities), the primary scool teaching texts. The used methodology in this study is the analysis of the conten t. the sampling used in this study, were some primary school texts from the 1st - 4th class: such as the ABC, Social Education, Albanian Language, biology, Musical Education, Reading, etc. The data collected from this study, result that all the above analysed texts, do have high stereotypical doses.

Keywords: gender roles, stereotypism, parenting styles, professions, games, primary school texts.

\section{Introduction}

The formation of the gender roles consist one of the most important aspects of the human development. They have a huge influencein the process of the familiar and social interactions. They also influence on the individual performance during all his way. For these reasons the study of the gender roles is very important.

The gender roles are formed through a socialization process. Depite the family, their coevals and media, the school is one of the most important agents, strongly influence in the gender role development. In the school system, despite the teachers and the coevals, the school texts have a strong influence in the gender roles development. In this context, the primary school text take a very important place because the children whos study these things, are in the middle childhood phase where the gender concioussness. Through these texts, the perception of the different gender roles is memorized in their unconsciousness and it is very difficult to be changed in the later years.

Is this the reason, that in different places of the world there have been many studies, connected with the influence of primary school text( in this sense even the primary texts) in the gender role formation! A series of studies on the gender prejudices in the scholar text, are made in different developed places, including the USA, France, Norwegian, Australia. England (Michel 1986). The recent findings are used in the feminist that according to Michel 1986 , were the first that asked the changes of the gender changes in the scholar texts.

In Albania, the study of the gender roles mass in the scholar text was very limited. It is done only one study connected with the gender stereotypes. This is showed even in the cases when the book authors are very young. The aim of the study is to explore the stereotypes in the teaching texts of the primary school in Albania. More specifically the study aims these objectives.

1. The frequency (how much of happen) the showing of the characters (figures feminine and masculine, in the primary school texts.

2. The way of the portraying the feminine and masculine connected with the family roles in the family roles

3. The way of portraying the feminines and masculines in the professional roles and the portraying the activities away from home (the economical and employment activities) in the primary school texts.

4. The way of describing the games according to the school text gender. 


\section{The Process of the Socialization of the Gender Roles}

Before starting with the specific literature review connected with the specific objectives of the study , there should be a definition of the terms, gender and gender roles. The gender has to do with the biological composiotion of the individual that differs a masculine from a feminine. This is defined from the genetical composition of the individual. The individuals behaviors, feminines and masculines and the kinds of the roles they choose, might be influenced, from the genetical, also from the social context. To differ the social roles and behaviors from the biological features, we use the term gender ( for the biological feature of the individual ) and the gender term (for the social roles and behaviors). The gender roles are defined as the (prescription and faiths connected with the emotions and behavoiurs of the women and men, as they are defined from the society and the culture (Anselmi and Law 1998, faqe. 195).

According to the World Health Organisation "the gender roles are referred to the roles, behaviours, activities, and attributes that a specific society consider them appropriate for men and women" (World Health Organization, 2013).

Gender affects essentially to the development of the individual, it affects a lot on how the individual interacts with the others and with the physical environment around him. Already, through many studies conclude that gender affects the individual choice to make friends, toys and professions. However, the most accepted point view today is that gender roles are determined by socialization, which is a continuous process through which an individual learns and accepts social norms. Socialization, works by punishing inappropriate behavior and stimulate appropriate behavior for women and men.

Developing the concept of gender and gender roles begins early in life and it is a continuous process. Early childhood and middle childhood have a great importance in this regard. In early childhood, children become aware of their gender and all the activities that they perform, associated with their gender identity ("I am a girl", "I'm a boy"). At this age, the family, schools and the media, exert a great impact which is stereotyped.

The theory of social imitation of Bandurës, the learning of gender roles is one of the most important in this field

According Bandura (1977), in the early childhood, the child learns about the social roles through the imitation process. Social learning theory developed by Bandura, notes the importance of the concept of imitating the behaviors of different models (which can be parents, the child's peers and other important characters to the child). According to this theory, boys learn to behave like boys, miming male and female behavior feminine learn behavior from imitating women, especially mothers and teachers. Laurens and Tshuma (1992) but also Fresher and Walker (1972) emphasize that social learning theory predicts that children learn about sex, correct behavior by gender role models that they see around themselves. In this process, there is a major role of punishment and reward mechanism. According to Bandura, when a guy imitates female behavior is punished, and when imitating a masculine behavior, he is rewarded.

Another important theory about the development of the concept of gender and gender roles is the cognitive development theory of Lawrence. According to Kohlberg, the gender development of the individual passes through three stages: early identity when the individual learns gender ("I am a girl"), then the concept of constant sex ("I always am a girl and when I grow up I will be a woman") and the later concept of gender constantancy ("Even if I wear pants, I will be a girl")

\section{The Literature Review, Regarding Gender Roles in Textbooks in Different Countries}

The studies regarding to the mode of presentation consisting the gender roles in textbooks, are categorized into two groups. The first group includes those who are focused entirely on text analysis and the analysis of illustrations (Koza 1994). It states that the illustrations often affect the mind of the reader, rather than written sentences. (Obura, 1991)

The second group includes those that focus exclusively on the written text (network of women working in Korea, 1997). There is a third group, including studies that have analyzed the studies of both components, as illustrated, and the written text, Obura (1991) and Michel (1986).

In many studies, are used qualitative and quantitative methods and in many cases are made statistical analysis

In many studies, it is evident that the frequency of occurrence of the male characters in textbooks, is greater than that of the female characters (Biraiman, 1988, Charlotte, 1976, Clarkson, 1993, Davies, 1995, Gupt and Su Yin, 1990, Koza, 1994, Michel, 1986, and Obura, 1991).

\section{Studies Conducted in Albania on Gender Stereotypes}

The study of gender stereotypes in textbooks in Albania is limited. In the knowledge of the author is making a study of only about textbooks by Gender Alliance in Albania. Which are analyzed in summary below. 
Throughout the study of the elementary texts (Gjermeni., E, Dhamo.M, Sinani..M et al., Tirana, 2005) noted that their focus illustrations were men. Only the texts of Social Education (1-4) it was less evident. There have been making constant efforts to maintain balance, not only in illustrations, but also representative characters, social roles, etc. In texts such as ABC, Reading, Mathematics and natural science, there are very evident that in the illustrations predominate boys. They, through body language, seem to be the leader or having dominant positions. They do not only occupy the largest part of the page of the book, but generally keep tracking tasks and features such as "doctors", "brave", "workers", "wise", "scientists", "promoters". At the same time, they appear as "naughty", "careless about themselves and hygiene", etc.

Figures of girls are mostly situated in the background of illustration. Even when girls have the leading role, they hide behind a phenomenon or phenomena where the figure remains dim.

Generally, there exist functions of the boys, brothers, friends etc., Always clean, the most beautiful, best in everything, but not the initiator. Generally, found at the premises of the home or school, and rarely in the yard, playing with friends.

The individual, regardless of gender, performs several roles in social institutions that may have gender interpretation. The family is a social institution somewhat more "conservative" than other institutions, in the sense that changes to it may happen more slowly. Gender roles of the individual in the family, are generally traditional.

\section{Research Methodology}

In this section, there will be a description about the goals and objectives of the study, the instruments are used to collect information, sample size and techniques used, and the way the data is analysed.

\section{Objectives of the Study} in Albania.

The purpose of this study was to explore stereotypes regarding gender roles in textbooks of elementary education

The objectives of this study are:

Specifically the study aims the following objectives:

1. The frequency (frequency) of performance (appearance) of characters (characters) females and males in elementary textbooks.

2. Forming the portrayal of women and men about their roles in the family (household activities at household level).

3. The way of portraying the men and women in relation to professional roles and activities outside the home (economic activities and employment) in elementary textbooks.

4. The way of describing games by gender, school textbooks.

The method used for the analysis of data

The method used to accomplish the purpose and objectives of the study is the analysis of the content. Through this method, analyzing each piece of information (the writing and illustrations) in textbooks selected for this study

In this study, there are used additionally, descriptions of phenomena and quantitative elements. Quantitative Analysis,see the presence or absence of male characters and the presence of different gender stereotypes, by analyzing the illustrations and written text content.

In analyzing the content there categorized descriptions, illustrations or any other message, in different groups and everything is calculated in numbers. (So, I made numerical encodings about lots of information that is analyzed depending on the goals and objectives of the study.

\section{The Choice of Sample}

The sample of this study consists of texts which are currently used in primary schools in Bangladesh. Texts, which were subjected to content analysis are: Primer, Social education 1, 2, 3, 4, 5, reading book 2, 3, 4, 5, natural sciences 3, 4, 5, Education Music 2, 3, 4, Reading 4, 5. Technological Training 5. To learn local history and geography 5.

In this study there are used four categories, to explore ways of describing gender roles in textbooks. A description of each category is based on content analysis of written language and illustrations in textbooks. When determining the categories of analysis are trying to be exclusive categories (ie to include all elements associated with this category). This, 
we think it has provided adequate level of reliability, the coding and analysis of gender roles, which are reflected in textbooks. Four categories defined to be analyzed in this study are: (1) the frequency of the appearance of male and female characters in textbooks, (2) gender roles in the family (3) economic roles (manufacturing) for women and men, (4) socio-political roles for men and women, and (4) toys for men and women as presented in textbooks of elementary education in Albania.

After detailed study and analysis, the low cycle texts in Albania, noted that Gender Stereotypes are widespread in all school textbooks currently used in schools.

What we found is that generally there is a frequency sufficiently increased portrayal of women in family roles (roles caregivers) about the family and the children. On the other hand, there is an almost total portrayal of men in work outside the home. It is noted, in all texts analyzed.See the chart for several groups of subjects.

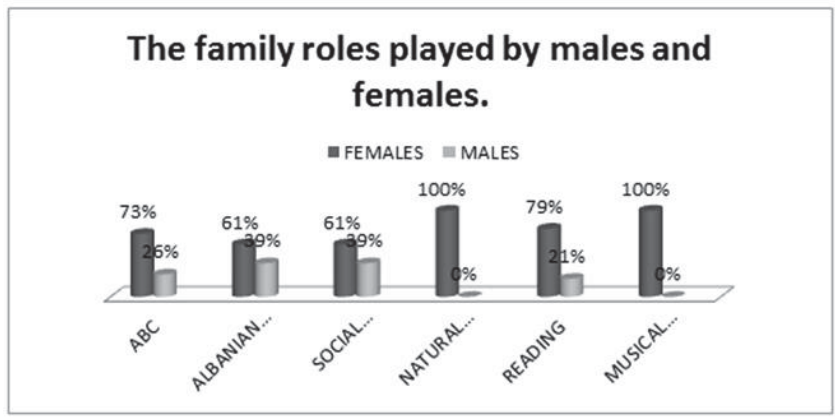

Regarding the professions, what can be generalized is that, in most cases are male professions, performed by men. While women are portrayed in most cases in professions (teachers, nurses, etc.). So it is found a pronounced gender division, about occupations, men carry trades traditionally considered masculine and women carry trades traditionally considered feminine..

A strong gender differentiation is shown in terms of games and toys, where the girls depicted in elementary texts, mainly in games traditionally feminine nature (girls presented playing with dolls, houses, etc.) and boys traditionally nature games male (boys appear to play football, horse, automatic etc.). (See the table below)

Table 2.

\begin{tabular}{|l|c|c|c|c|}
\hline \multirow{2}{*}{$\begin{array}{l}\text { a. professions, that are considered traditionally feminine,how many are done by males, and how many are done by females? } \\
\text { b. professions, that are considered traditionally for males ,how many are done by males, and how many are done by females? }\end{array}$} \\
\hline \multirow{2}{*}{ Texts groups } & \multicolumn{2}{|c|}{ Feminine professions } & \multicolumn{2}{c|}{ Masculine professions } \\
\cline { 2 - 5 } & $\begin{array}{c}\text { How many are done by } \\
\text { females? }\end{array}$ & $\begin{array}{c}\text { How many are done by } \\
\text { females? }\end{array}$ & $\begin{array}{c}\text { How many are done by } \\
\text { females? }\end{array}$ & $\begin{array}{c}\text { How many are done by } \\
\text { females? }\end{array}$ \\
\hline ABC & $27 / 90 \%$ & $3 / 10 \%$ & 0 & $24 / 100 \%$ \\
\hline Language & $161 / 65 \%$ & $86 / 35 \%$ & $5 / 6 \%$ & $85 / 94 \%$ \\
\hline Social Education & $67 / 78 \%$ & $19 / 22 \%$ & $2 / 4 \%$ & $44 / 96 \%$ \\
\hline Natural sciences & $8 / 57 \%$ & $6 / 43 \%$ & 0 & $16 / 100 \%$ \\
\hline Musical education & $11 / 79 \%$ & $3 / 21 \%$ & 0 & $3 / 100 \%$ \\
\hline Reading & $6 / 50 \%$ & $6 / 50 \%$ & 0 & $4 / 100 \%$ \\
\hline
\end{tabular}

\section{Reccomendation}

Eliminating gender stereotypes in elementary texts, constitutes a long and very complex, involving several actors, such as central educational institutions, publishing houses, authors of textbooks and teacher preparation. Addressing the problem of gender stereotypes in elementary school textbooks should include all these actors.

Below there are some recommendations based on the findings of this study and the experience of other countries on this aspect. 


\section{For the Ministry of Education and Science}

- Developing the guidance on the requirements specified for maintaining gender balance in the content and illustrations of the elementary textbooks. This may be an instruction included in the overall direction of the Ministry of Education and Science, designs textbook or a special instruction specifically for this purpose.

- Continuous monitoring by the Ministry of Education of the implementation of the requirements for maintaining gender balance in the textbooks of the authors and publishing houses, in such a way that, not allowed to publish books with gender stereotypes.

- providing training to teachers on issues of gender equality, in order, to enable them, in the identification and elimination of gender stereotypes in textbooks and other books school aid

- Training teachers of elementary concerning kenceptet gender equality, so that, to enable them to use such material in class in order to develop, gender equality among students.

- Training and equipping teachers with clear instructions regarding the methodology of transmission of the content of texts, in order, to promote gender balance

- Ministry of Education and Science in cooperation with publishing houses organize specific training, with groups of authors of textbooks regarding insurance requirements for gender balance in textbooks and shmangjene gender stereotypes.

For the publishing houses:

- Drafting of the houses, which include the publication of textbooks guidelines for editors and authors of the texts concerning the specific requirements to reflect the gender balance in textbooks

- $\quad$ publishing houses, should have a staff, for gender equality to consult with the writers.

\section{References}

Acker, S. 1987. Feminist Theory and the study of Gender Education. International review of education 33.

Alimehmeti. Z, Kraja. N, Edukimi muzikor 4, publishing house Morava, Tiranë. 2008. ISBN978-99956-26-02-0

Ajrullai. L, Zenelaj. F, Natural science 3, publishing house Albas; Tiranë, 2011, ISBN 978-9928-02-097-0

Ajrullai. L, Zenelaj. F, Dituri Natyre 5, Shtëpia Botuese AlbasTiranë, 2012, ISBN 978-9928-02-132-8.

Bandura, Albert. Social Learning Theory. Englewood Cliffs, NJ:Prentice-Hall, 1977)

Bannars, G A \& Kabira, W M. 1994. Girls' education. An agenda for change. Nairobi: FAWE.

Basow, S A. 1993. Gender stereotypes and roles. California: Brookes/Cole Publishing Company.

Bardhi. L; Gjino. Gj; technology tranings 5; publishing house : Mediaprint; Tiranë 2011; ISBN 978-99956-93-52-7

Beci. B;Abc, Shtëpia Botuese Mediaprint, Tiranë, 2011, ISBN 978-99956-93-44-2

Berger, A S. 1991. Media analysis techniques (Revised edition). London: Sage Publishers

Biraimah, K L. 1988. Gender division of labor in Ëest African Secondary Schools textbooks (PhD thesis)

Brummelen Van Harro. December 1990. The role of textbooks in inducting children into society. Journal of educational thought. 24 (3A): 135-137.

Cangonji. A, Fejzo. A, musical education 4 publishing house Pegi; Tiranë 2011 ISBN 978-99956-58-93-9

Charlotte, A. 1976. One Perspective on Sexist Texts (Mimeograph).

Clarkson, P. 1993. Gender, ethnicity and textbooks. Australia mathematicsteacher. 
